\section{'GoldRush' Apple}

Jeffrey A. Crosby', Jules Janick, and Paul C. Pecknold

Department of Botany and Plant Pathology and Horticulture, Purdue University, West Lafayette, IN 47907-1165

Joseph C. Goffreda

Department of Plant Science, Rutgers-The State University, New Brunswick, NJ 08903

\section{Schuyler S. Korban \\ Department of Horticulture, University of Illinois, Urbana, IL 61801.}

Additional index words. Malus $\times$ domestica, Venturia inaequalis, fruit breeding, disease resistance

'GoldRush' is a late-maturing yellow apple (Malus $\times$ domestica Borkh.) with excellent fruit quality and long storage ability combined with field immunity to apple scab incited by Venturia inaequalis (Cke.) Wint., a high level of resistance to apple mildew incited by Podosphaera leucotricha (En \& EV.) Salm., and moderate resistance to fire blight incited by Erwinia amylovora (Burr.) Winslow. It was named 'GoldRush' to emphasize its golden ground color and bronze blush combined with its "rush" of flavor.

'GoldRush' is the tenth apple cultivar developed by the cooperative breeding program of the Indiana, Illinois, and New Jersey Agricultural Experiment Stations (Crosby et al., 1992). Fruiting has been observed at various locations in the United States, including the Purdue Univ. Horticultural Research Farm for 13 years and Rutgers Univ. for 3 years.

The fruit is characterized by a complex, rich spicy flavor with a high degree of acidity and sweetness. Acidity moderates in cold storage, resulting in exceptional overall quality after 2 to 3 months. The apple retains its complex sprightly flavor and crisp, firm texture for at least 7 months at $1 \mathrm{C}$. The cultivar has been rated consistently as the highest quality apple after storage of all selections or cultivars tested at Purdue Univ. The fruit produces little cuticular wax and does not become greasy even after 7 months in storage. Moisture content of the fruit will need to be managed by various methods to prevent dehydration in storage, but even when shriveling occurs, the flesh texture remains crisp. Fruit thinning will be required to produce large fruit.

\section{Origin}

The original seedling was planted in May 1973 in the HE block on the Purdue Horticul-

Received for publication 28 Oct. 1993, Accepted for publication 26 Jan, 1994. Journal paper 13,995 of the Purdue Univ. Agricultural Expt. Station. The cost of publishing this paper was defrayed in part by the payment of page charges. Under postal regulations, this paper therefore must be hereby marked advertisement solely to indicate this fact.

'Current address: Stark Brothers Nurseries and Orchards Co., Louisiana, MO 63353. ture Research Farm, West Lafayette, Ind., where its position was row 4 , tree 16 (HER4T16) and had the designation PRI 27506 in our breeding records. The seedling is derived from a cross made in 1972 at Urbana, Ill., of 'Golden Delicious' as the seed parent with Co-op 17 (PRI 1689-110) as the pollen parent (Fig. 1). Resistance to scab is based on the $V_{f}$ gene derived from Malus floribunda 821 (Crosby et al., 1992). The seedling was selected in Oct. 1980 by E.B. Williams, a longtime leader of the Purdue apple breeding program. It was released for advanced testing under the designation Co-op 38 (Crosby et al., 1993). It has been evaluated at Purdue Univ., Rutgers Univ., and by private growers and nurseries in California, Illinois, Indiana, Missouri, and Washington, and in Bologna, Italy.

\section{Description}

'GoldRush' fruit (Fig. 2) range from 64 to $76 \mathrm{~mm}$ in diameter and are ovate in shape. The skin is greenish-yellow with an occasional bronze to red blush at harvest, becoming entirely deep yellow in storage. The color is much more pronounced than in 'Golden Delicious', and the skin is smooth, nonwaxy, thin to medium in thickness with conspicuous, russetted, round to stellate lenticels similar to Midwestern-grown 'Golden Delicious'. Flesh is medium-coarse-grained, firm, crisp, pale yellow, and nonbrowning. The flavor is complex, spicy, and sprightly acid at harvest. We rated quality as very good to excellent at harvest, and it improves after cold storage and retains a high rating for 7 months at $1 \mathrm{C}$. Flavor retention, acidity, and crisp flesh remain outstanding after long-term storage. Season of
Fig. 1. Pedigree of 'GoldRush' apple. maturity is 3.5 to 4.0 weeks after 'Delicious', 24 to 31 Oct. at Lafayette, Ind. (lat. $40^{\circ} \mathrm{N}$ ). Compared to 'Golden Delicious', 'GoldRush' is firmer and has higher soluble solids concentration and more acidity, resulting in a more desirable sugar: acid ratio (Table 1). The low internal ethylene concentration of 'GoldRush' may be responsible for its longer storage life.

The tree is slightly upright and moderately vigorous with limited branching and a strong tendency to develop a central leader; crotch angles are wide. The tree is heavily spurred. Fruits are borne singly on short spurs and are not prone to preharvest drop. The tree has been propagated by bud grafting on seedling, EMLA 111, EMLA 7, and EMLA 9 rootstock. Flowering occurs after 'Golden Delicious' and slightly earlier than 'Enterprise'.

'GoldRush' apple was tested extensively as a seedling in the greenhouse for resistance to apple scab, and it was evaluated in the field for resistance to other major apple diseases. Scab resistance is based on the absence of sporulation after repeated greenhouse inoculations with $V$. inaequalis races 1 through 5 using Williams' (1978) methods. 'GoldRush' is rated moderately resistant to fire blight based on field evaluation, with only a few strikes observed in 1 year on young trees. Resistance to powdery mildew was rated as high as 2 in 1 year based on a $\mathrm{O}$ (no infection) to 5 (severe infection) scale. Susceptibility to cedar-apple rust [incited byGymnosporangium juniperi-virginianae (Schw.)] is similar to that of 'Golden Delicious', with severe infection noted in New Jersey. Bitter pit and water core have been absent. The selection is susceptible to sooty blotch incited by Gloeodes pomigena (Sch.) Colby.

The following detailed description follows Zielinski (1955) and uses color designations according to the Royal Horticultural Society Colour Chart of 1938 and 1941.

\section{FLOWER}

Corolla: $\quad$ Average of $43 \mathrm{~mm}$ in diameter at anthesis.

Petals: $\quad 14 \times 21 \mathrm{~mm}$.

Color: Rose bengal 25/1 to magenta 27/1 (bud) fading to white margined or patterned with rose bengal $25 / 4$ to magenta $27 / 1$ or lighter (open flowers). Adaxial surface of petals has more color and distinct patterns than abaxial surface. None of the petals are totally white, even at petal fall.

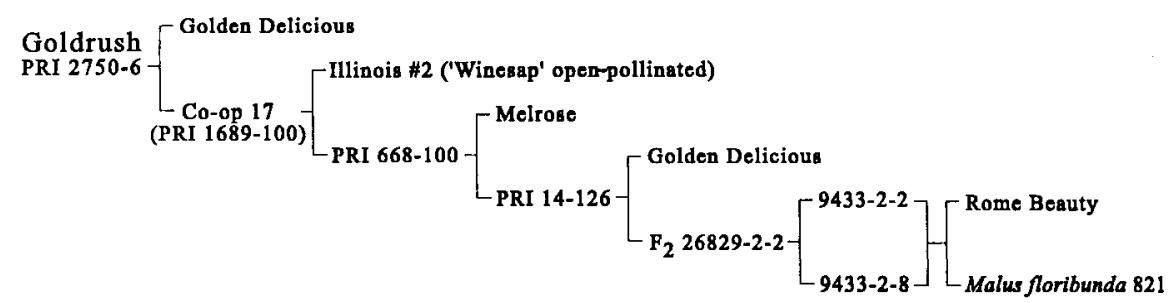




\section{FRUIT}

Ovate, regular; length : width ratio $=0.94$

Size: $\quad$ Average diameter, 70 to $76 \mathrm{~mm}$.

Color: Greenish at harvest, becoming entirely yellow in storage [from lemon yellow (plate 4/1) to saffron yellow (plate 7/2)]. Develops heavy blush on the sunexposed side of the fruit.

Skin: $\quad$ Smooth, nonwaxy, tender, thin to medium in thickness; very conspicuous, russetted, round to stellate, scattered lenticels, not rough to the touch.

Ster ${ }^{\mathrm{n}} \quad$ Medium to long, thin to medium.

Cavity: $\quad$ Acute, medium depth, medium width, occasional russet.

Basin: $\quad$ Medium depth, medium breadth, sloping sides, regular surface.

Calyx: Persistent, open, erect to recurved.

Calyx tube: Conical.

Stamens: Median.

Core-lines: Clasping.

Core: Median, usually closed, mediumsized.

Carpels: Round, emarginate, smooth.

Seeds: $\quad$ Full compliment, acute, nontufted.

Flesh:

Texture: Medium-coarse-grained, firm, crisp.

Color: Indian yellow (plate 6/3).

Quality: Spicy and sprightly acid at harvest; spicy, rich, full flavor; good to excellent quality that improves in storage.

Maturity

season: 20 to 30 Oct. at West Lafayette, Ind.; 3.5 to 4.0 weeks after 'Delicious'.

Keeping

quality: Excellent quality improves in storage and retains texture and flavor for at least 7 months at $1 \mathrm{C}$.

Use: Winter dessert apple, appropriate for medium- and long-term storage.

\section{TREE}

Form and

habit: Slightly upright, moderately vigorous; limited branching, with a

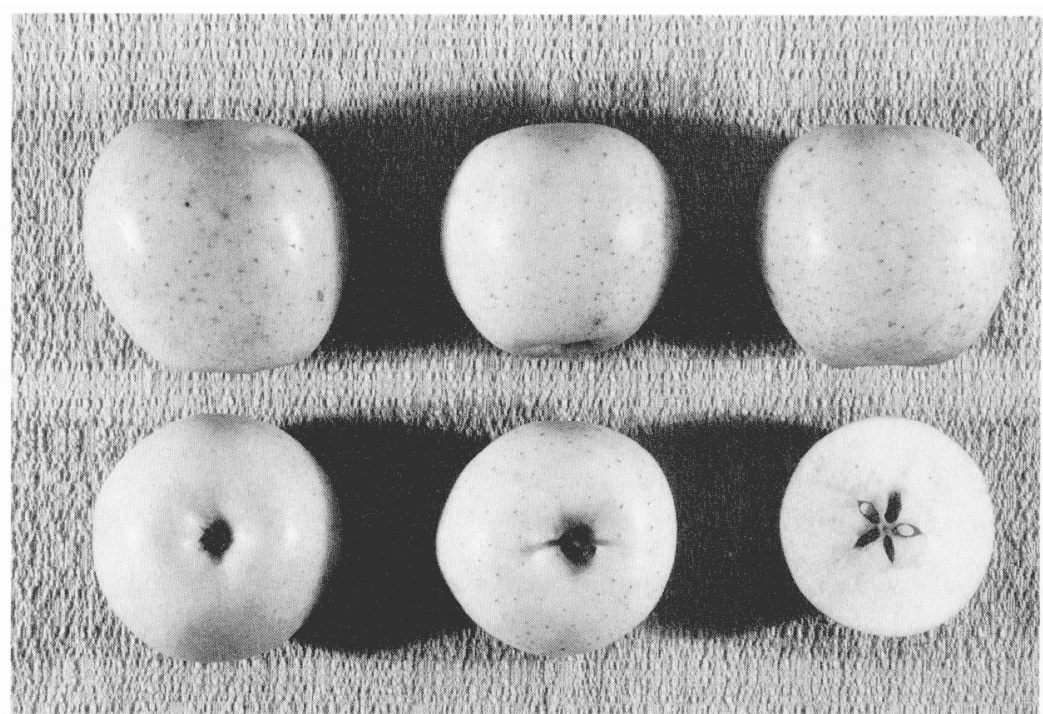

Fig. 2. 'GoldRush' apple fruit.

Table 1. Quality characteristics of 'Gold Rush' and 'Golden Delicious: apples stored at $0 \mathrm{C}$ for 4 and 7 weeks, respectively.

\begin{tabular}{lcc}
\hline \hline Variable & Gold Rush & Golden Delicious! \\
\hline Pressure (N) & $93 \pm 1.2$ & $76 \pm 1.2$ \\
Starch rating (iodine test) & $4.5 \pm 0.16$ & $5.2 \pm 0.13$ \\
Soluble solids concentration (\%) & $13.7 \pm 0.3$ & $12.2 \pm 0.3$ \\
pH & $3.24 \pm 0.01$ & $3.58 \pm 0.03$ \\
Titratable acidity (g malic acid/100 ml) & $0.61 \pm 0.03$ & $0.28 \pm 0.02$ \\
Core ethylene (ppm) & $8.34 \pm 0.49$ & $77.5 \pm 12.8$ \\
\hline
\end{tabular}

${ }^{2}$ Harvested 28 Oct.

${ }^{\text {yH} H a r v e s t e d ~} 8$ Oct.

strong tendency to develop a central leader and crotch angles of $60^{\prime \prime}$ to $90^{\circ}$ and almost full spur-type bearing habit. Fruit are borne singly on short spurs and hang well on the tree even when over-ripe; some biennial tendency if overcropped.

Leaves: Ovate to oval; serrate to doubleserrate margins; apex acute to acuminate, base acute to rounded; length : width ratio $=$ 1.87. Leaf petioles show anthocyanin pigmentation, which can be intense in tissues exposed to the sun.

\section{Availability}

Budwood is available for test purposes to federal and state experiment stations. Trees will be available from licensed nurseries in 1994. The Purdue Research Foundation has applied for a plant patent under the name Co-op 38 .

\section{Literature Cited}

Crosby, J.A., J. Janick, P.C. Pecknold, S.S. Korban, P.A. O'Conner, S.M. Ries, J. Goffreda, and A. Voordeckers. 1992. Breeding apples for scab resistance 1945-1990. Fruit Var. J. 46 145-166.

Crosby, J.A., J. Janick, P.C. Pecknold, S.S. Korban, S.M. Ries, J. Goffreda, and A. Voordeckers. 1993. Coop 32 to 38: Seven disease resistant apple selections released for advanced testing. Purdue Univ. Sta. Bul. 658.

Williams, E.B. 1978. Handling the apple scab organism in the laboratory and greenhouse. Proc. Apple and Pear Scab Wkshp., 11 July 1976, Kansas City, Mo. Amer. Phytopathol. Soc. p. 16-18.

Zielinski, Q.B. 1955. Modem systematic pomology. Brown, Dubuque, Iowa. 